Research Article

\title{
Supply Chain Analysis of Rice (Oryza sativa L.) Sub-Sector in Kanchanpur District, Nepal
}

\author{
Sandeep Airee $^{1^{*}, B \text { Bishnu Raj Ojha }}{ }^{2}$, Ankit Ojha ${ }^{1}$, Asmita Bhandari $^{1}$ \\ ${ }^{1}$ Agriculture and Forestry University (AFU), Rampur, Chitwan, Nepal \\ ${ }^{2}$ Department of Genetics and Plant Breeding, AFU, Rampur, Chitwan, Nepal
}

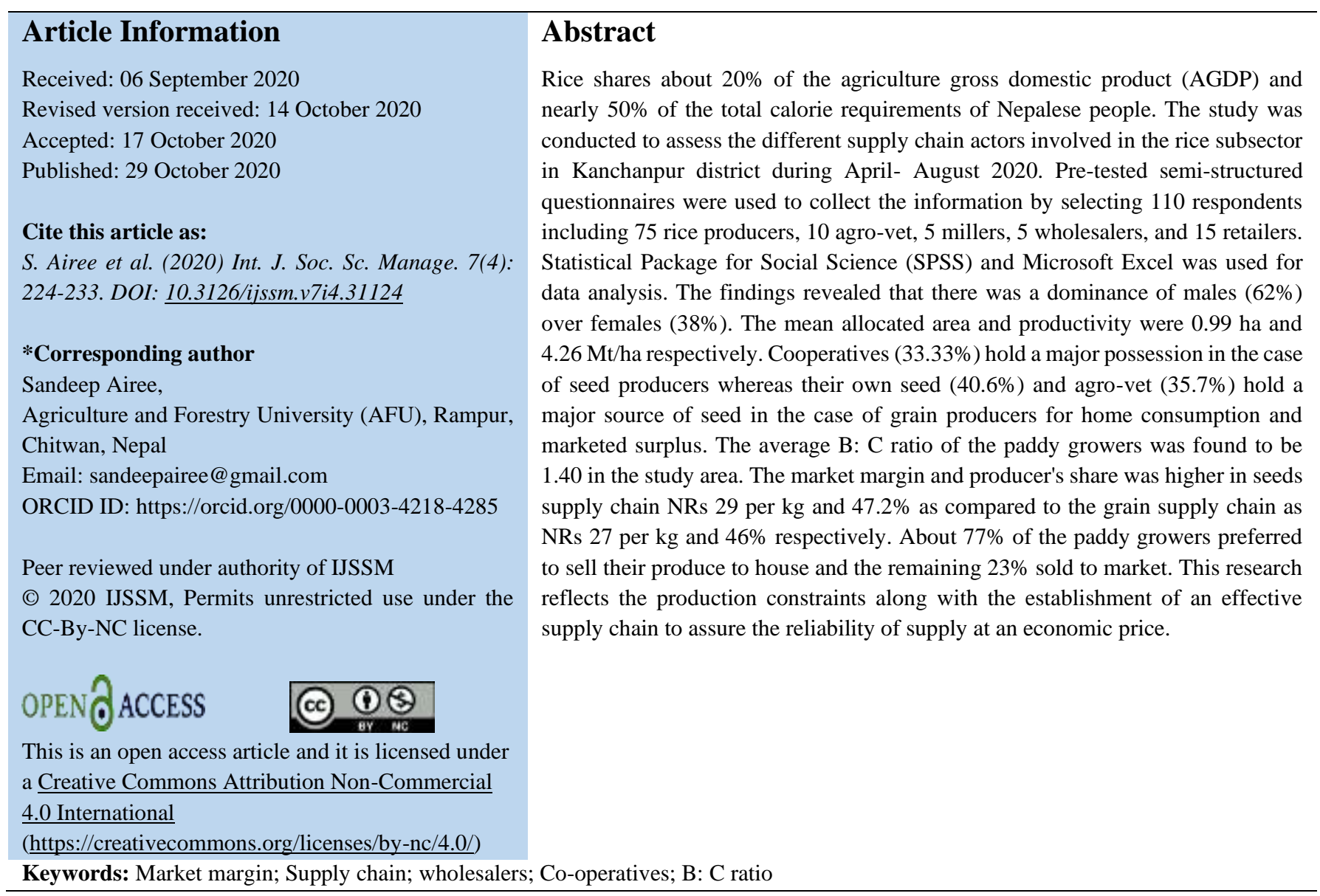

\section{Introduction}

Rice (Oryza sativa L.) is annual self-pollinated and semiaquatic staple food grain crop for more than $60 \%$ of the world's population, of which $95 \%$ is produced and consumed in Asia (Alam, 2009). In Nepal, the total area under rice cultivation was 1.4 million hectares with an annual production of 5.6 million tons of paddy with an average productivity of $3.76 \mathrm{Mt} / \mathrm{ha}$ (MOALD, 2019/20). Rice shares $20 \%$ to the agriculture gross domestic product (AGDP) in Nepal and contributes nearly 50\% to the total calories requirements of Nepalese people (NARC, 2016). 
Paddy cultivation is extremely labor-intensive, therefore, requires more labor in comparison to other cereals (CDD, 2015). Kanchanpur which is famous for its productive land and high production of rice about 46215 ha of land is under rice cultivation with the production of $179314 \mathrm{Mt}$ of production and 3.88 ton/ha (MOAD, 2019). The popular varieties of rice in the district are Sarju-52, Radha-4, Bahuguni, Hardinath, Sawa mansuli, Sabitri, etc. Seeds are generally processed by the co-operatives whereas paddy grains are processed by the millers.

Farmers of Kanchanpur are mostly engaged in subsistence and conventional farming practices due to a lack of skills and technology adoption. Post-harvest losses of 25-30\% of the total seed and grain value have been reported in rice (Taruvinga, 2014). Rice imports to Nepal increase by $20.68 \%$ as compared to last year and reached up to Rs. 24.50 billion during the first 10 months of the current fiscal year (2019/20). The import of food grains from India has increased since the price of rice in India is $12 \%$ lower (mainly due to subsidies on fertilizers and electricity for irrigation) (WFP, 2008). Moreover, a large no. of peri-urban fertile land has been modified for residential purposes due to urbanization and population growth. The production of local rice has not been able to meet the increasing demand for rice provoked by population growth and change in consumer habits. The middlemen play a crucial role in the rice marketing system with their own determine price higher than government price leading to unstable and lower farm-gate prices for the farmers.

Self-sufficiency in rice is a major concern for Government of Nepal, because it's hugely important to Nepalese society, culture, and also a vital source of livelihood, especially for poor and rural people. Timely supply a sufficient amount of quality seeds to boost up crop yields by $15-25 \%$. Postharvest losses of paddy can be reduced by using appropriate storage practices, access to market, transportation facilities. This research would be helpful to enforce collective marketing and market intelligence system to reduce the involvement of large middlemen along with the achievement of economic prices to farmers. Likewise, this provides ample information to check the fluctuation of price, impose price regulations policy e.g. floor and ceiling price to marginalized farmers. The present study is also aimed at an in-depth investigation of the effective supply chain management and constraints related to the rice subsector to assure the reliability of supply at an economic price.

\section{Materials and Methods}

\section{Study Area and Sampling Design}

Kanchanpur district is a part of Province No. 7 in the terai plain located in the Mahakali Zone of Nepal. It coordinates $28^{\circ} 50^{\prime} \mathrm{N}$ latitude and Longitude $80^{\circ} 20^{\prime} \mathrm{E}$. The district has a tropical climate with hot summer and cold winter. The district was purposefully selected because it's famous for productive land and potentially identifiable paddy growing farmers. A total of 110 samples including 75 rice producers from 3 municipalities namely as Bhimdutta, Bedkot, and Krishnapur (@25 growers/ Municipality) were selected by using cluster random sampling whereas the remaining 10 agro-vet and suppliers, 5 millers and traders, 5 wholesalers, and 15 retailers were selected by using purposive sampling. Based on production attributes, paddy growers were categorized into different groups namely into seed producers, marketed surplus grain producers, and grain producers for home consumption.

\section{Data Collection and Analysis}

The study collected primary information from farmers by using pre-tested semi-structured questionnaires through face to face interviews in May- July 2020. Focus Group Discussion (FGD) and Key Informants Interview (KII) were carried out to supplement the collected information. Likewise, secondary data were collected annual reports, newsletters, relevant articles, PMAMP, Krishi Diary 2076 BS. The collected raw data were entered, edited, and were analyzed with the help of Microsoft Excel and Statistical Package for Social Science (SPSS).

\section{Benefit Cost Analysis}

Hence, the benefit-cost analysis was carried out by using the formula

B/C Ratio = Total Gross Return $(\mathrm{GR}) /$ Total Variable Cost
$(\mathrm{TVC})$

Where,

Total Gross return (NRs) (GR) $=$ (Total quantity of paddy sold $(\mathrm{Kg}) \times$ Price per unit of paddy $)+$ Revenue from the sale of by-product

Total Variable Cost $($ TVC $)=$ this cost estimates the expenditure incurred by the farmer in the cultivation of crops.

\section{Marketing Margin and Producers Share}

It can be calculated by the difference between the farm gate price and the retailer's price as follows:

Marketing Margin (NRs): Retailer's Price (Pr) - Farm Gate Price (Pf)

Producers Share reflects producers' access and integration with the market. It was estimated by using the following formula,

$\mathrm{Ps}=(\mathrm{Pf} / \mathrm{Pr}) \times 100 \%$

Where, 
Ps $=$ Producer Share, $\mathrm{Pf}=$ Producers Price $($ Farm gate Price $)$ and $\mathrm{Pr}=$ Retailer's Price (Price paid by consumers)

\section{Supply Chain Analysis}

A supply chain map was prepared based on primary data. It analyzes the farm gate price of the product, price spread, and price control mechanism until it reaches the consumers. This network includes different activities, people, entities, information, and resources.

\section{Indexing}

It simply allowed ranking the various problems related to the production and marketing faced by paddy growers. The perceptions of various problems by farmers were analyzed by using 5 points of scaling technique comparing most serious, serious, moderate and least serious at all using scores $1.00,0.80,0.6,0.4$ and 0.2 . The priority of scale was computed by using the following highlighted formula:

$\mathrm{I}_{\mathrm{imp}}=\Sigma\left(\mathrm{S}_{\mathrm{i}} \times \mathrm{F}_{\mathrm{i}} / \mathrm{N}\right)$

Where,

$\mathrm{I}_{\mathrm{imp}}=$ Index of Importance

$\mathrm{S}_{\mathrm{i}}=$ Scale Value

$\mathrm{F}_{\mathrm{i}}=$ Frequency of importance given by the respondent

$\mathrm{N}=$ Total number of respondents.

\section{Results and Discussions}

\section{Socio-Demographic and Economic Characteristics of Respondents}

The data shown in Table 1 revealed that the dominance of male respondents $(61.3 \%)$ over females $(38.7 \%)$ in the study area. The average family size of the respondent during the study was found to be 7.4 which were higher than the district average family size (5.49) (NPHC, 2011). Most of the seed producers were Janjati $(46.7 \%)$ which indicated that Janjati is more liable or prefers to seed production to raise living standards. Chhetri (35.7\%) and Brahmin (39\%) hold a major possession in marketed surplus and grain producers for only home consumption respectively. The majority of the families in the study area were nuclear type $(61.3 \%)$. The majority of the respondents were found to be literate in seed producers $(73.4 \%)$, marketed surplus $(60.7 \%)$, and grain producers for home consumption only $(93.75 \%)$. The statistical tools based on the Chi-square test revealed a statistically significant difference between seed producers, marketed surplus, and grain producers for only home consumption in case of gender and ethnicity composition of the respondent at $1 \%$ and $5 \%$ level of significance whereas non-significant in case of educational status, family size and family type.

\section{Distribution Based on Paddy Cultivated Area and Productivity}

The average landholding size of respondents in the study area was 0.99 ha and productivity was $4.27 \mathrm{Mt} / \mathrm{ha}$ which was higher in comparison to national productivity (3.76Mt/ha) by $0.51 \mathrm{Mt} / \mathrm{ha}$ (MOAD, 2018/19). The farmers having intermediate mean farm size 1.06 ha are mainly focused on seed production as in further large cultivated area it was found to be difficult in management of quality seed production, lack of market, and technology adoption. Likewise, the share of the marketable surplus farmers has the largest mean farm size of 1.60 ha likely to prefer to produce paddy grain for marketing purposes. Study by (Chauhan and Singh, 2002) showed that, marketed surplus of paddy is positively related to the volume of production as well as with area under crop. Hence, the study concluded that the paddy cultivated area was statistically significant whereas paddy productivity was statistically non-significant between seed producers, marketed surplus grain producers, and grain producers for only home consumption at a $1 \%$ level of significance which is shown in Table 2.

\section{Adoption of Production Technology}

The assessment of different production technology adopted by paddy producers is shown in Table 3. The study indicated that $56 \%$ of respondents have access to irrigation facilities which was higher than the national average i.e. $36.4 \%$ of the total rice ecosystem under rainfed (MOALD, 2013). Likewise, about $60 \%$ and $64.3 \%$ have access to irrigation facilities in seed producers and marketed surplus grain producers whereas $53.1 \%$ have no access to irrigation facilities in case of grain producers for only home consumption. Likewise, Co-operatives (33.33\%), own seeds $(40.6 \%)$, and agro-vet $(35.7 \%)$ hold a major possession in the case of seed producers, grain producers for only home consumption (40.6\%), and marketed surplus grain producers respectively. The study indicated $60 \%$ in seed producers, $68 \%$ in marketed surplus grain producers and $82 \%$ in grain producers for only home consumption had not participated in production technology-based training programs.

About $62.7 \%$ have not still practiced contract farming during the study. This indicated that paddy growers are still at high risk in case of product failure discouraging them in the commercialization of paddy production. The study revealed that about $60 \%$ of paddy farmers have no access whereas all the seed producers have access to seed quality tests in Regional Seed Testing Laboratory, Sundarpur. The study revealed that the majority $(70 \%)$ of the paddy growers in the study area had no provision of a moisture meter. This indicated the lack of skills and low adoption of marketing technology by farmers. 
Table 1: Demographic characteristics of paddy growers by production attributes in Kanchanpur, Nepal.

\begin{tabular}{|c|c|c|c|c|c|}
\hline Variable & $\begin{array}{l}\text { Overall } \\
(n=75)\end{array}$ & $\begin{array}{l}\text { Seed Producers } \\
(n=15)\end{array}$ & $\begin{array}{l}\text { Marketed surplus } \\
\text { grain producers } \\
(\mathrm{n}=28)\end{array}$ & $\begin{array}{l}\text { Grain Producers } \\
\text { for home } \\
\text { consumption only } \\
(n=32)\end{array}$ & $\begin{array}{l}\text { Chi-Square } \\
\text { value }\end{array}$ \\
\hline \multicolumn{6}{|l|}{ Gender of the } \\
\hline respondent & $46(61.3)$ & $8(53.3)$ & $11(39.3)$ & $27(84.4)$ & $13.308 * * *$ \\
\hline Male & $29(38.7)$ & $7(46.7)$ & $17(60.7)$ & 5 (15.6) & $(\mathrm{P}=0.001)$ \\
\hline \multicolumn{6}{|l|}{ Female } \\
\hline Family Size & 7.4 & 7.67 & 8.39 & 6.4 & $\begin{array}{l}2.375^{\mathrm{ns}} \\
(\mathrm{P}=0.09)\end{array}$ \\
\hline \multicolumn{6}{|l|}{ Ethnicity } \\
\hline Brahmin & $25(33.33)$ & $2(13.3)$ & $7(25)$ & $16(50)$ & $12.307 * *$ \\
\hline Chettri & $28(27.3)$ & $5(33.33)$ & $10(35.7)$ & $12(37.5)$ & $(\mathrm{P}=0.045)$ \\
\hline Janjati & $20(26.7)$ & $8(53.33)$ & $8(28.7)$ & $3(9.4)$ & \\
\hline Dalit & $2(2.7)$ & & $1(3.6)$ & $1(3.1)$ & \\
\hline $\begin{array}{l}\text { Family Type } \\
\text { (Nuclear) }\end{array}$ & $46(61.3)$ & $10(66.67)$ & $20(71.42)$ & $21(65.6)$ & $\begin{array}{l}1.712^{\mathrm{ns}} \\
(\mathrm{P}=0.425)\end{array}$ \\
\hline $\begin{array}{l}\text { Education of } \mathrm{HHH} \\
\text { (Literate) }\end{array}$ & $56(67.9)$ & $11(73.4)$ & 17 (60.7) & $30(93.75)$ & $\begin{array}{l}20.850^{\mathrm{ns}} \\
(\mathrm{P}=0.053)\end{array}$ \\
\hline
\end{tabular}

Table 2: Distribution based on Paddy cultivated area and productivity in Kanchanpur, Nepal

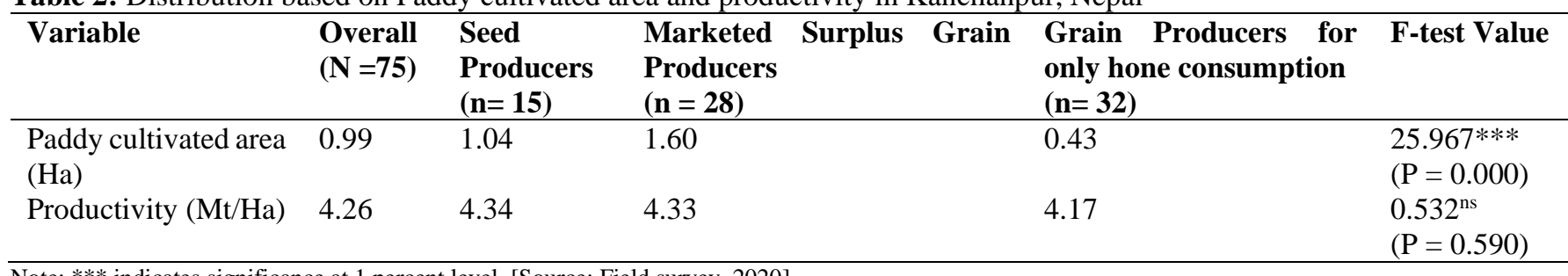

Note: *** indicates significance at 1 percent level. [Source: Field survey, 2020]

Table 3: Adoption of Production Technology among paddy farmers by production attributes in Kanchanpur, Nepal

\begin{tabular}{|c|c|c|c|c|c|}
\hline Variable & $\begin{array}{l}\text { Overall } \\
(N=75)\end{array}$ & $\begin{array}{l}\text { Seed } \\
\text { Producers } \\
(\mathbf{n}=\mathbf{1 5})\end{array}$ & $\begin{array}{l}\text { Marketed Surplus Grain } \\
\text { Producers }(n=28)\end{array}$ & $\begin{array}{l}\text { Grain Producers for only } \\
\text { home consumption }(n=32)\end{array}$ & $\begin{array}{l}\text { Chi-square } \\
\text { value }\end{array}$ \\
\hline \multicolumn{6}{|l|}{ Irrigation type } \\
\hline Irrigated & $42(56)$ & $9(60)$ & $18(64.3)$ & $15(46.9)$ & $1.959^{\mathrm{ns}}$ \\
\hline Un irrigated & $33(44)$ & $6(40)$ & $10(35.7)$ & $17(53.1)$ & $\begin{array}{l}\text { (at } 2 \mathrm{df} \\
\mathrm{P}=0.376)\end{array}$ \\
\hline \multicolumn{6}{|l|}{$\begin{array}{c}\text { Source of seed } \\
\text { purchase }\end{array}$} \\
\hline Own Seed & $18(24)$ & $3(20)$ & $3(10.7)$ & $13(40.6)$ & $26.340 * * *$ \\
\hline Agro-Vet & $14(18.7)$ & $4(26.7)$ & $10(35.7)$ & $3(9.4)$ & (at $6 \mathrm{df}$ and \\
\hline DADO & $22(29.3)$ & $3(20)$ & $8(28.6)$ & $12(37.5)$ & $\mathrm{P}=0.000)$ \\
\hline Co-operative & $21(28)$ & $5(33.3)$ & $7(25)$ & $4(12.5)$ & \\
\hline \multicolumn{6}{|l|}{ Participation in } \\
\hline \multicolumn{6}{|l|}{ Training } \\
\hline Yes & $21(28)$ & $6(40)$ & $9(32)$ & $6(18)$ & $2.668^{\mathrm{ns}}$ \\
\hline No & $54(72)$ & $9(60)$ & $19(68)$ & $26(82)$ & $\begin{array}{l}\text { (at } 2 \mathrm{df} \text { and } \\
\mathrm{P}=0.263 \text { ) }\end{array}$ \\
\hline \multicolumn{6}{|l|}{ Contract farming } \\
\hline Yes & $28(37.3)$ & $6(40)$ & $13(46.4)$ & $9(28.1)$ & $2.195^{\mathrm{ns}}$ \\
\hline No & $47(62.7)$ & $9(60)$ & $15(53.6)$ & $23(71.9)$ & $\begin{array}{l}\text { (at } 2 \mathrm{df} \\
\mathrm{P}=0.334)\end{array}$ \\
\hline \multicolumn{6}{|l|}{ Seed Test } \\
\hline Yes & $29(39)$ & $15(100)$ & $10(35.7)$ & $4(12.5)$ & $33.135 * * *$ \\
\hline No & $46(61)$ & & $18(64.3)$ & $28(87.5)$ & $\begin{aligned} & (\text { at } 2 \text { df P } \\
= & 0.00)\end{aligned}$ \\
\hline \multicolumn{6}{|l|}{ Moisture Meter } \\
\hline Yes & $22(30)$ & $4(27)$ & $9(32)$ & $9(28)$ & $0.181^{\mathrm{ns}}$ \\
\hline No & $53(70)$ & $11(73)$ & $19(68)$ & $23(7)$ & $(\mathrm{P}=0.914)$ \\
\hline
\end{tabular}




\section{Cost Analysis of Paddy Seed and Grain}

The comparative study is based on production attributes for the cost incurred in paddy production which was represented in Table 4 . The average total cost of production was NRs 96626/Ha. The least cost of production was found in marketed surplus grain producers as NRs $90587 / \mathrm{Ha}$ whereas the highest was obtained in seed producers as NRs 108700/Ha. Likewise, the highest total revenue was obtained in seed producers as NRs $170097 / \mathrm{H}$ and least in grain producers for only home consumption as NRs 106423/Ha. The highest B: C ratio was obtained in seed producers (1.56) least in grain producers for only home consumption (1.15) i.e. if we invest one rupee, then we can get the returns of Rs. 1.56 from the business, which indicate that our investment is financially feasible. Similar finding was obtained i.e. The B: $\mathrm{C}$ ratio was 1.51 was found greater than 1.14 in dang district revealed from the research carried by (Thapa, 2018)). So; rice production can run smoothly in Kanchanpur. The major reason for the highest B: C ratio in seed producers was due to the high farm gate price of seeds (NRs 28 per $\mathrm{kg}$ ) received by the farmers to their satisfaction level, less presence of middlemen, and intricate marketing channel. The study indicated that about $21.98 \%$ of total production cost was incurred by tillage operation on paddy cultivation in Kanchanpur district. The marketed surplus grain producers expense maximum i.e. $23.70 \%$ and minimum by seed producers $(17.56 \%)$ of total paddy production cost on tillage operation. Moreover, marketed surplus also expensed maximum i.e. $17.03 \%$ and minimum in seed producers $(13.70 \%)$ of total paddy production cost on harvesting operation.

\section{Market and Marketing Behavior of Paddy Farmers}

All the paddy growers in the study area were successfully categorized and analyzed into two categories as seller and non-seller. Figure 5 indicates $41 \%$ of paddy growers sold their produce and the remaining $59 \%$ did not perform any selling activities (Fig. 1).

Table 4: Cost Analysis of paddy production based on production attributes in Kanchanpur, Nepal

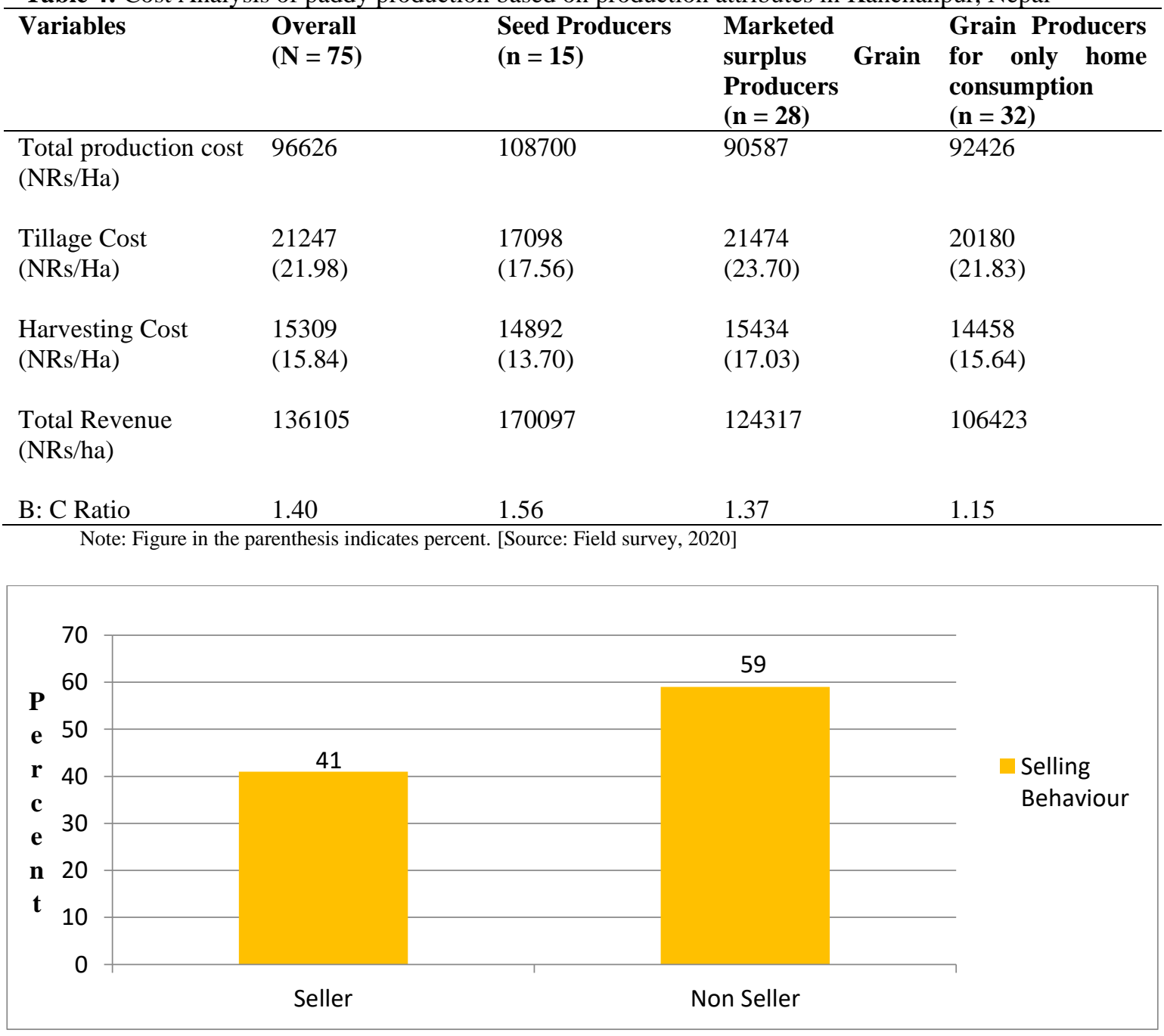

Fig. 1: Paddy farmer's category on the basis of selling behavior in Kanchanpur. 
The Figure 2 revealed the study of the venue of seed sale by paddy farmers. The figure indicated that the majority of the paddy growers preferred to sell their produce to House $77 \%$ and the remaining small portion sold to market $23 \%$.

Figure 3 revealed that about one-third $(33.33 \%$ ) of paddy farmers sold their produce grains to cooperatives followed by local traders (28\%), Consumers $(21.3 \%)$, and Millers $(17.3 \%)$.

\section{Satisfaction from Farm Gate Price}

Different farmers have a different satisfaction level on the farm gate price they received. About $49.3 \%$ are found to be less satisfied with farm gate prices in the study area. Meanwhile, all the seed producers were found to be satisfied completely whereas in marketed surplus only $3.6 \%$ of farmers found to be satisfied with farm gate price received which results in statistically significant at $1 \%$ level as shown in Table 5.

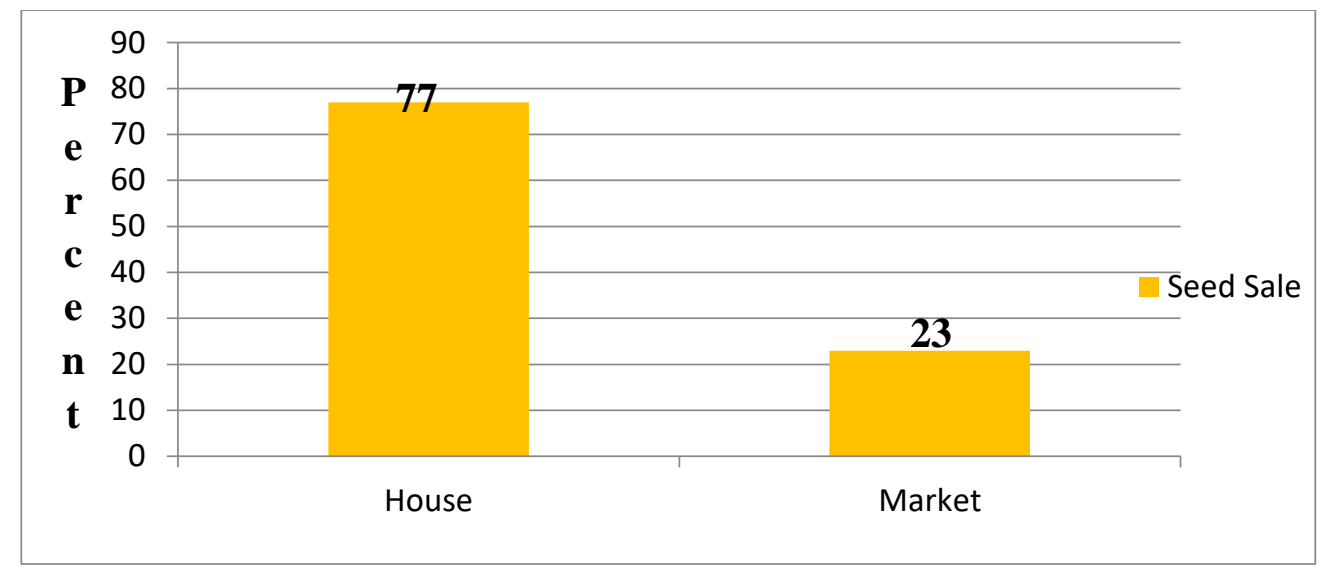

Fig. 2: Venue of Seed Sale by Paddy Farmers in Kanchanpur.

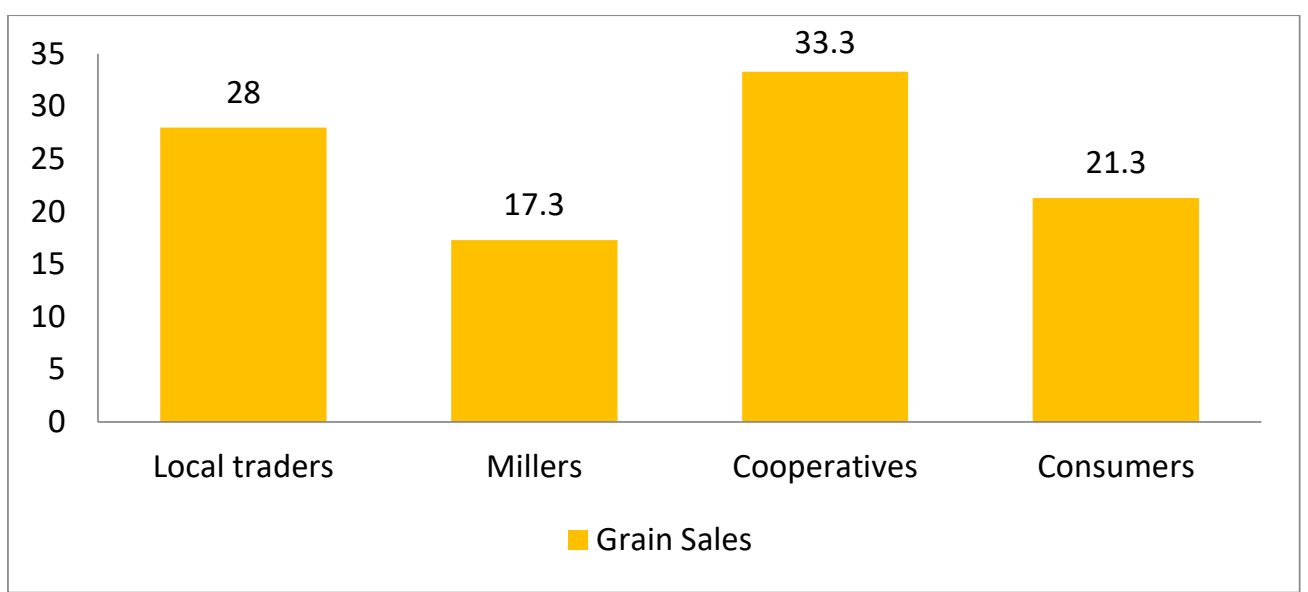

Fig. 3: Sale of grain by Paddy farmers to various supply chain actors.

Table 5: Satisfaction from Farm gate price on the basis of production attributes in Kanchanpur,

\begin{tabular}{|c|c|c|c|c|}
\hline $\begin{array}{l}\text { Satisfaction } \\
\text { Level }\end{array}$ & $\begin{array}{l}\text { Overall } \\
(N=75)\end{array}$ & $\begin{array}{l}\text { Seed Producers } \\
(n=15)\end{array}$ & $\begin{array}{l}\text { Marketed Surplus } \\
\text { Grain producers } \\
(\mathbf{n}=\mathbf{2 8})\end{array}$ & $\begin{array}{l}\text { Chi-Square } \\
\text { Value }\end{array}$ \\
\hline Satisfied & $18(24)$ & $15(100)$ & $1(3.6)$ & \\
\hline $\begin{array}{l}\text { Moderately } \\
\text { satisfied }\end{array}$ & $20(26.7)$ & $0(0.00)$ & $6(21.4)$ & $\begin{array}{l}64.102 * * * \\
(\mathrm{P}=0.000)\end{array}$ \\
\hline Less Satisfied & $37(49.3)$ & $0(0.00)$ & $21(75)$ & \\
\hline
\end{tabular}


Table 6: Production Constraints faced by paddy farmers in Kanchanpur, Nepal

\begin{tabular}{llllllll}
\hline Constraints & $\mathbf{1}$ & $\mathbf{0 . 8}$ & $\mathbf{0 . 6}$ & $\mathbf{0 . 4}$ & $\mathbf{0 . 2}$ & Index Value & Rank \\
\hline Low Farm gate Price & 20 & 17 & 16 & 8 & 14 & 0.66 & II \\
Poor extension Services & 17 & 13 & 13 & 12 & 20 & 0.59 & III \\
Unavailability of farm inputs & 33 & 18 & 15 & 6 & 3 & 0.79 & I \\
Poor quality of farm inputs & 2 & 9 & 16 & 25 & 23 & 0.45 & V \\
Labor shortage & 3 & 18 & 15 & 24 & 15 & 0.52 & IV \\
\hline
\end{tabular}

[Source: Field survey, 2020]

\section{Major Constraints faced by farmers in paddy production}

There are many constraints pertaining by the farmers on paddy production. This study attempted to find some of them as perceived by the farmers. Similarly, five points scaling $(1,0.8,0.6,0.4$, and 0.2$)$ technique was used to find the relative intensity or priority of the constraints. The value obtained from ranking scale revealed that unavailability of farm inputs has the highest index value (0.79) and least index value was of poor quality of farm inputs (0.45) (Table 6 ). Thus, the priority of the major constraints faced by the paddy farmers in the study areas followed descending sequence order of unavailability of farm inputs, low farm gate price, poor extension services, labor shortage and poor quality of farm inputs. Subedi (2019a) used the scaling technique to identify the constraints associated with the Potato production in Terai region of Nepal. This above formula was also applied (Shrestha \& Shrestha, 2017) to rank the problems associated with maize seed production. Subedi et al. (2019b) used this technique to explore the problems associated with wheat production.

\section{Marketing Margin and Producer's Share}

The average cost of production for paddy farmers was NRs 22.68 per $\mathrm{kg}$ of rice in the study site. Moreover, seed producers usually sold their produce to cooperatives at NRs 26 per $\mathrm{kg}$ whereas marketed surplus sold their produce to local traders and millers at NRs 23 per kg and NRs 25 per $\mathrm{kg}$ for coarse and fine grains respectively. Among them, local traders sold their produce to millers at NRs 28 per $\mathrm{kg}$ and millers sold to wholesalers, retailers, and ultimate consumers at NRs 40 per $\mathrm{kg}$ and NRs $55-60$ per $\mathrm{kg}$ for processed coarse and fine grains respectively. The price marked by the wholesalers of processed fine and coarse grains is NRs 60-65 and NRs 45 respectively depending upon the varietal quality and quantity. Finally, the retailers dispensed the product to ultimate consumers at NRs 45-50 and NRs 65-75 for processed coarse and fine grains respectively. The average transportation cost incurred was NRs 70 per quintal at local and NRs. 110 per quintal at the regional and domestic levels. Likewise, the marketing cost incurred was NRs 120 per quintal and NRs. 180 per quintal at the local and at the regional level respectively. The average labor cost for loading and unloading the bulk amount of produce was NRs 28 per quintal. The market price of rice seeds is usually determined by the annual board meeting between cooperatives, seed companies, and concerned governmental bodies. Similarly, the price of paddy grains was fixed by the District Chamber of commerce and Industry.

Hence, Market margin for rice seeds $=$ NRs 55- 26

$=$ NRs 29 per $\mathrm{kg}$

Likewise,

Market margin for paddy grains (Coarse grains) $=$ NRs. 5023

$=$ NRs 27 per $\mathrm{kg}$

The market margin was higher in seeds supply chain NRs 29 per $\mathrm{kg}$ and lower in grain supply chain NRs 27 per kg which might be due to unstable and low-price policy, illegal selling activities by rice brokers in border areas.

Similarly,

Producers Share of rice seed producers $=(26 / 55) * 100$

$=47.27 \%$

Producers Share of paddy grain producers $=(23 / 50) * 100$ $=46 \%$

Similarly, the producer's share was higher in the seeds supply chain $(47.27 \%)$ and lower in the grains supply chain (46\%).

\section{Supply Chain of Paddy Grains and Seed}

The analysis of supply chain is intended to provide a systematic knowledge of the flow of the goods and services from their origin to the final destination.

\section{Marketing Chain in Seed Producers}

The purchase price for seed by co-operatives at Rs 26 per $\mathrm{kg}$ after its harvest. Co-operatives, seed farms, and companies are responsible for post-harvest management practices. The collected seed samples were analyzed at Regional Seed Testing Laboratory, Sundarpur for germination, physical purity, and moisture test. Finally, they are packed and label in jute bags of $35-50 \mathrm{~kg}$ each and distributed within Kanchanpur district and Mahakali zone.

Marketing Chain in Marketed Surplus Grain Producers Marketed surplus grain producers purchase seeds from cooperatives, DADO, and agro-vet. They sold their produce to 
local traders $(35 \%)$, millers $(20 \%)$, Co-operatives $(25 \%)$, and directly to consumers (20\%). Rice millers conduct all the processing functions and $60 \%$ of processed rice is distributed to wholesalers, $30 \%$ to retailers, and $10 \%$ to ultimate consumers within the Kanchanpur district. Wholesalers perform $85 \%$ of the supply of processed rice to retailers and the remaining $15 \%$ directly to the consumers. (Singh, 2005) identified four different types of marketing channels in Madhya Pradesh of India among them producer to wholesaler to retailer to consumer, where two middlemen are involved, was the largest chain used by $41.63 \%$ respondents of his study. (Takele, 2010) revealed that wholesalers and millers are the most important buyers of rice from producers, about $45 \%$ and $27 \%$, respectively.

The market price of rice is usually affected by (i) method of sale, (ii) mode of payment, (iii) means of transportation, and types of road.

\section{Marketing Chain in Grain Producers for Only Home Consumption}

These paddy farmers supply their all the produce directly to the miller for processing operations and use for their home consumption only and not any portion is supplied to market.

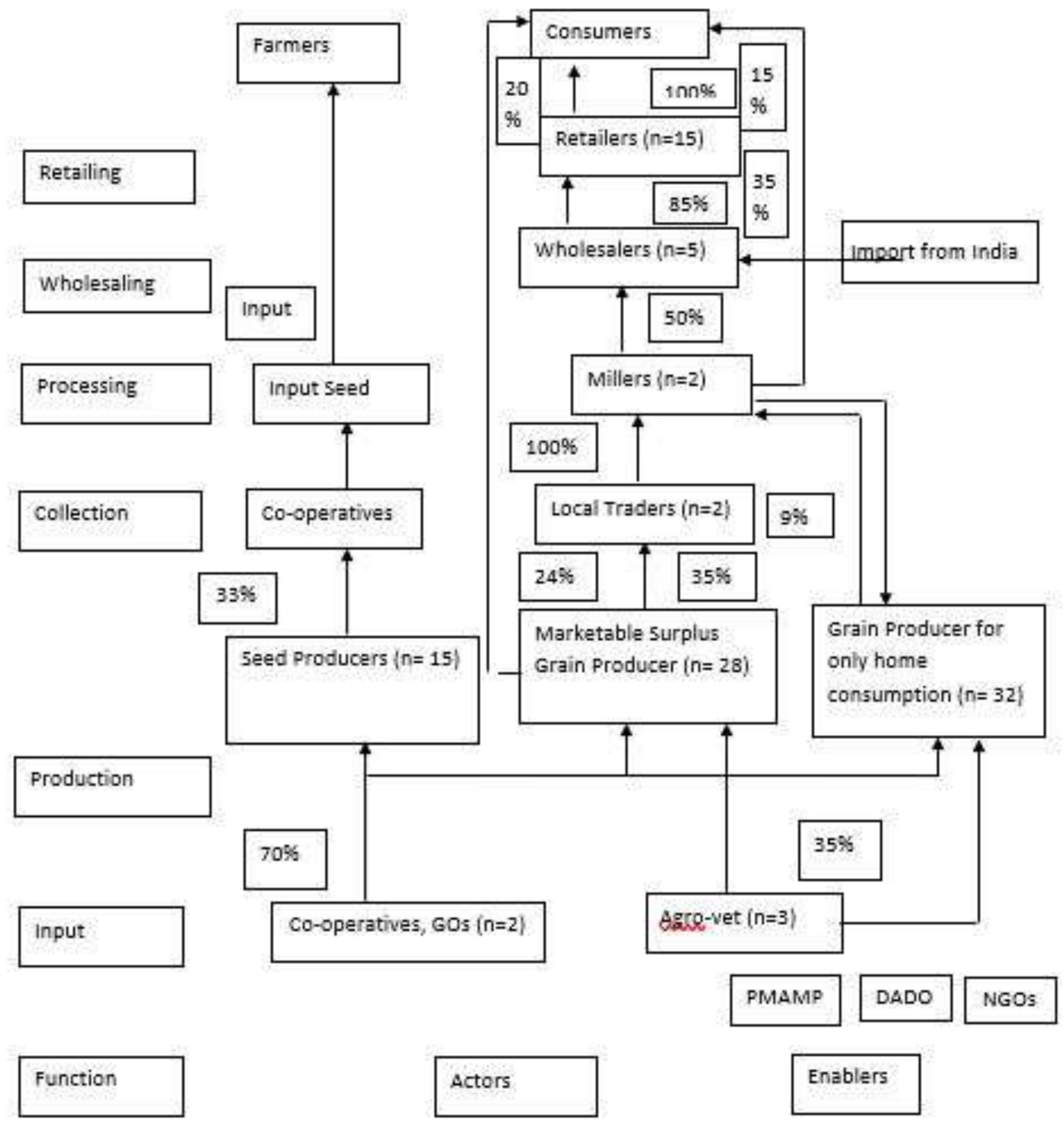

Fig 4: Supply Chain Map of rice sub-sector in Kanchanpur district of Nepal. 


\section{Processing and Packaging}

Seeds are generally processed by co-operatives whereas paddy grains are being processed by millers. The collected seed samples by co-operatives and seed production farms are allowed for seed testing at Regional Seed Testing Laboratory, Sundarpur. They are packed and labeled in plastic and jute bag $50 \mathrm{~kg}$ each for the distribution to farmers.

In the case of paddy grains, Millers collected the harvested paddy grains from farmers, village traders, and wholesalers within Kanchanpur district and announces the price levels for milled rice considering the milling charge. They processed 100 tons of paddy grains annually. It involves grading, de-husking, grinding, and polishing. During the study, we found the recovery percent of paddy grains was $60-65 \%$ and that of rice husk and barn was $20-25 \%$ and 10 $\%$ respectively. On average, paddy rice produces $25 \%$ hulls, $10 \%$ bran, and $65 \%$ white rice (Saunders, 1979). The paddy grains are generally stored in jute sacks bags of $35 \mathrm{~kg}$ and $50 \mathrm{~kg}$ and are transported to the market. The total cost incurred in transportation and handling, labor for loading and unloading, electricity, and packaging was NRs 30, NRs 10 , and NRs 15 per quintal per trip respectively.

\section{Conclusion}

Kanchanpur is famous for its productive land and high production of rice. The majority of the farmers less than 1 ha cultivated area rely on labor-intensive, subsistence, and conventional cultivation practices with the increased cost of production which seizes farmer's potential to achieve satisfiable farm return. Paddy growers have very limited access to irrigation water and still rely on rainwater. The B: $\mathrm{C}$ ratio was found to be highest in seed producers (1.74) due to the high farm gate price from rice seeds. The marketing margin (NRs. 29/kg) and producers share (47.27\%) was higher in seeds as compared to grains. Processing and packing of rice seeds and paddy grains are done by cooperatives and millers, respectively. Recovery percentage was found $60-65 \%$ (grains), $20-25 \%$ (rice husk) and 10\% (rice bran). The supply chain analysis of the rice sub-sector was largely constrained by unavailability of quality input, lack of technical knowledge, technical support services, and absence of collection centers, poor market infrastructure, poor road and transport, and unavailability of processing units. This research suggests the government and policymakers foster the collective marketing and market intelligence system to reduce the involvement of middlemen, control the price spread, and helps the farmers to achieve the economic price of their product. Farmers play a crucial role in the supply chain so priority attention should be given by encouraging them to adopt Good Agriculture Practices, contract farming, spring rice varieties, and promoting farm mechanization. The study should be focused on the post-harvest loss of grains at different stages of marketing functions along with an assessment of the import of fine rice.

\section{Authors' Contributions}

S. Airee performed the survey, analyzed the data, and wrote the paper. B.R. Ojha supervised entire research and manuscript preparation. A. Ojha was responsible for the edition and revision of the paper. A. Bhandari was involved in the literature review, preparation of questionnaires, and the publication process.

\section{Conflict of Interest}

The authors declare that there are no conflicts of interest regarding publication of this Manuscript.

\section{Acknowledgement}

The authors would like to acknowledge PM-AMP and AFU for providing financial and technical support. Further they are thankful To Mr. Govind Raj Joshi, Senior Horticulture Officer, Krishi Bikash Farm, Kanchanpur, Mr. Tej Bahadur Subedi, Secretary, Ministry of Land Management, Agriculture and Cooperatives, for their immense support, insightful comments and devoting valuable time from initiation of work to ship-shaping the manuscript. Above ground, we are indebted to Amrit Dumre, Aashish Ghimire, and Suraj Acharya for their generosity, guidance in data collection, and analysis throughout my research.

\section{References}

Alam MM, Ali MH, Amin AK and Hasanuzzaman M (2009) Yield attributes, yield and harvest index of three irrigated rice varieties under different levels of phosphorus. Advances in biological research 3(3-4):132-139.

CDD (2015) Rice varietal mapping in Nepal: Implication for development and adoption. Hariharbhawan, Lalitpur, Nepal.

Chauhan VK and Singh R (2002) Marketed surplus of paddy- A regression analysis. National level Quarterly. Journal of Agricultural Marketing 45 (2).

MOALD (2019) Statistical Information on Nepalese agriculture.Singh Durbar, Kathmandu, Nepal.

MOALD (2013) Statistical Information on Nepalese Agriculture. Singha Durbar, Kathmandu, Nepal.

NARC (2016) Nepal Agricultural Research Council. Lalitpur, Nepal: Rice Knowledge Bank.

NPHC (2011) National Population and Housing Census 2011. Kathmandu, Nepal: Central Bureau of Statistics.

Saunders RA (1979) Tropical Food. Chemistry and Nutrition Academic Press NY, USA: 191-216. 
Singh M (2005) Economics of Production and Marketing of Vegetables in Madhya Pradesh, India. Indian Institute of Forest Management .

Takele A (2010) Analysis of rice profitability and marketing chain: The case of Fogera Woreda, South Gondar Zone, Amhara national regional state, Ethiopia (Doctoral dissertation, Haramaya University). CGIAR .

Taruvinga CM (2014) Appropriate seed and grain storage systems for small-scale farmers: key practices for DRR implementers. Agris.

WFP (2008) SPATIAL integration of the rice market. Kathmandu:Wprld Food Programme, Nepal.
Shrestha A and Shrestha J (2017) Production, problems and decision making aspects of Maize seed producers in Banke District, Nepal. Azarian Journal of Agriculture, 4 (6): 212216.

Subedi S, Ghimire YN, Gautam S, Poudel HK, and Shrestha J (2019a) Economics of potato (Solanum tuberosumL.) production in terai region of Nepal. Archives of Agriculture and Environmental Science, 4(1): 57- 62

Thapa TL, Bhattarai C, Khatri B and Bhusal K (2018) Supply chain analysis of rice sub- sector in Dang district, Nepal. International Journal of Applied Sciences and Biotechnology 6(4): 319-326. 